\title{
Computers in psychology: A survey of instructional applications
}

\author{
N. JOHN CASTELLAN, JR. \\ Indiana University, Bloomington, Indiana 47405
}

\begin{abstract}
This paper describes the results of a survey of psychology department chairpersons and faculty concerning the use of instructional computing in undergraduate instruction. The survey summarizes characteristics of departments and faculty, past and future change in instructional computing, current instructional computing activities, and perceived needs for future development in this rapidly changing area.
\end{abstract}

Over the past several years, CONDUIT has periodically assessed the "state of the art" concerning the application of computers in a variety of disciplines, particularly the physical, natural, social, and behavioral sciences. These surveys are useful benchmarks for marking the rate of infusion of instructional computing in these disciplines and illustrates some useful comparisons between usage in disciplines. Psychology has long been an important part of these periodic surveys (see Castellan, Bailey, Lehman, McClelland, \& Starr, 1977). An earlier survey covering the social sciences was done in 1972 (see Cline, 1972). During the 1978-1979 year, a survey was conducted by CONDUIT, some results from which are summarized here.

Initial questionnaires were mailed to a sample of psychology department chairpersons to survey the extent of the use of computers in instruction in their departments. (The departments were those listed by the American Psychological Association as departments having undergraduate degree programs in psychology.) The 199 chairpersons who responded provided general demographic information about their institutions, departmental faculties, students, and curricula. In addition, they provided names of faculty members in their departments who used computers in undergraduate instruction. While it is important to assess the overall usage of computers in instruction, the primary focus of the survey was on undergraduate instruction. Individual questionnaires were provided for distribution to the appropriate faculty. Individual faculty questionnaires $(\mathrm{N}=342)$ focused on the type of computer(s) used, languages, support services (personnel and operating budget), details on the manner in which computing was then being used (instruction, research, data analysis, experimental control, simulation, etc.), and planned

This survey was supported by an NSF grant to CONDUIT. Copies of surveys in other disciplines and information about CONDUIT are available from CONDUIT, P.O. Box 388 , Iowa City, Iowa 52244. Requests for reprints of this paper should be addressed to the author at the Department of Psychology, Indiana University, Bloomington, Indiana 47405. future activities involving computers. In addition, specific information usage patterns within subareas of academic psychology were obtained and analyzed.

The typical department surveyed has approximately 12 FTE faculty and approximately 150 undergraduate majors (see Table 1). Five percent of the departments award an associate (or no) degree, 56\% award only bachelor's degrees, and 39\% award graduate degrees. Seventy percent of the departments have faculty who use computers in instruction, although $57 \%$ of that use is "infrequent" and $43 \%$ is "moderate" or "extensive" (see Table 2). A somewhat surprising result of the survey

Table 1

General Characteristics of Departments Surveyed

\begin{tabular}{|c|c|c|c|}
\hline \multicolumn{2}{|c|}{ Faculty Size } & \multicolumn{2}{|c|}{ Psychology Majors } \\
\hline $\mathbf{N}$ & Percentage & $\mathbf{N}$ & Percentage \\
\hline$<5$ & 25 & $0-10$ & 20 \\
\hline $5-10$ & 34 & $11-100$ & 28 \\
\hline $11-15$ & 12 & $101-200$ & 15 \\
\hline $16-20$ & 11 & $201-300$ & 10 \\
\hline \multirow[t]{3}{*}{$>20$} & 18 & $301-400$ & 8 \\
\hline & & $401-900$ & 8 \\
\hline & & $>900$ & 11 \\
\hline
\end{tabular}

Table 2

Departmental Faculty Use of Computers

Category Percentage

Number of Faculty Using Computers

$\begin{array}{lr}\text { None } & 30 \\ 1 & 26 \\ 2 & 19 \\ 3 & 12 \\ 4-5 & 7 \\ 6-10 & 3 \\ >10 & 3\end{array}$

Extent of Computer Use

$\begin{array}{lr}\text { None } & 30 \\ \text { Infrequent } & 40 \\ \text { Moderate } & 27 \\ \text { Extensive } & 3\end{array}$


Table 3

Faculty Using Computers as a Function of Department Characteristics

\begin{tabular}{|c|c|c|c|c|c|c|}
\hline \multirow[b]{2}{*}{ Category } & \multirow[b]{2}{*}{$\mathrm{N}$} & \multicolumn{5}{|c|}{ Percentage of Faculty Using Computers } \\
\hline & & None & $1-24$ & $25-49$ & $50-74$ & $75-100$ \\
\hline \multicolumn{7}{|c|}{ Highest Degree Offered } \\
\hline Bachelor's & 111 & 37 & 25 & 22 & 10 & 6 \\
\hline Master's & 31 & 32 & 52 & 16 & 0 & 0 \\
\hline Doctoral & 40 & 11 & 85 & 4 & 0 & 0 \\
\hline Overall & 188 & 30 & 44 & 17 & 6 & 3 \\
\hline \multicolumn{7}{|c|}{ Department Size (Number of Faculty Employed) } \\
\hline$<5$ & 47 & 53 & 0 & 21 & 17 & 9 \\
\hline $5-10$ & 67 & 36 & 30 & 27 & 5 & 3 \\
\hline $11-15$ & 24 & 13 & 83 & 0 & 0 & 4 \\
\hline $16-20$ & 21 & 14 & 76 & 10 & 0 & 0 \\
\hline$>20$ & 34 & 12 & 82 & 6 & 0 & 0 \\
\hline Overall & 193 & 30 & 44 & 17 & 6 & 4 \\
\hline \multicolumn{7}{|c|}{ School Size (Number of Students Enrolled) } \\
\hline$<1000$ & 20 & 48 & 10 & 24 & 10 & 2 \\
\hline $1001-5000$ & 97 & 35 & 30 & 22 & 8 & 5 \\
\hline $5001-10000$ & 24 & 29 & 67 & 4 & 0 & 0 \\
\hline $10001-15000$ & 19 & 5 & 84 & 11 & 0 & 0 \\
\hline$>15000$ & 22 & 14 & 86 & 0 & 0 & 0 \\
\hline Overall & 191 & 31 & 43 & 17 & 6 & 4 \\
\hline
\end{tabular}

was that the percentage of faculty using computers in instruction was greater in small institutions than in large institutions. That is, while a greater number of larger departments have at least one faculty member who uses computers in instruction, the percentage of faculty who use computers in instruction within a department decreases with increasing department size (see Table 3). A similar result was observed in assessing faculty instructional computing use as a function of school size: In the smaller schools in which any instructional computing is done, a larger percentage of the faculty use computers than in larger institutions. Because comparative computer usage in different disciplines is often sought, it is worth noting that psychology is similar to physical science disciplines and political science in the proportion of departments in which computers are used in instruction (approximately $70 \%$ or more). Among sociology, education, and biology departments, less than $60 \%$ have faculty who use computers in teaching. These comparisons are in Table 4 . The ranks of

Table 4

Faculty Computer Use by Discipline

\begin{tabular}{lrrrrr}
\hline & \multicolumn{5}{c}{$\begin{array}{c}\text { Percentage of Faculty } \\
\text { Using Computers }\end{array}$} \\
\cline { 2 - 6 } \multicolumn{1}{c}{ Department } & None & $1-24$ & $25-49$ & $50-74$ & $75-100$ \\
\hline Math/Statistics & 26 & 24 & 23 & 16 & 11 \\
Political Science & 27 & 43 & 22 & 7 & 2 \\
Physics & 29 & 23 & 18 & 16 & 14 \\
Chemistry & 29 & 27 & 21 & 15 & 8 \\
Psychology & 30 & 44 & 18 & 6 & 3 \\
Sociology & 39 & 33 & 19 & 7 & 2 \\
Education & 46 & 40 & 12 & 1 & 1 \\
Biology & 48 & 34 & 12 & 3 & 3 \\
\hline
\end{tabular}

the faculty surveyed were $34 \%, 33 \%, 27 \%$, assistant, associate, and full professors, respectively. The balance of respondents $(6 \%)$ were instructors or others. Since the previous survey, the rank of faculty using computers in instruction has increased. In the earlier survey, slightly less than $50 \%$ of the faculty were associate or full professors; in the present survey, the number was $60 \%$. While this increase is due in part to the general aging of faculty in general, it also suggests that innovation, at least with regard to use of computers, spreads upward.

\section{CHANGES IN PATTERNS OF COMPUTER USE}

Part of the survey dealt with perceptions of faculty and chairpersons concerning the changes in computer use in instruction and constraints on the effective use of computers in instruction. Individual faculty members reported more increased use of computers than their chairpersons did; however, both had similar expectations concerning future use for instructional computing (see Table 5). Faculty and chairpersons also rated constraints on computer usage (see Table 6). The greatest constraint perceived by department chairpersons was lack of faculty training $(60 \%)$. The greatest constraint perceived by faculty was lack of time (52\%). For both faculty and chairpersons, lack of equipment was the second greatest constraint. Particularly salient to the faculty was the lack of support help in the form of staff programmers, technicians, and engineers. The perceived lack of academic reward was noted by over one-third of the respondents.

Faculty members were asked what factors affected both past and future changes in the use of computers in 
Table 5

Changes in Instructional Computing

\begin{tabular}{lcccc}
\hline & \multicolumn{2}{c}{$\begin{array}{c}\text { Change in Level of Instructional } \\
\text { Computing (in Percentages) }\end{array}$} \\
\cline { 2 - 5 } & $\begin{array}{c}\text { Reported in } \\
\text { Past 2 Years }\end{array}$ & \multicolumn{2}{c}{$\begin{array}{c}\text { Anticipated in } \\
\text { Next 2 Years }\end{array}$} \\
\cline { 2 - 5 } & $\begin{array}{c}\text { Chair- } \\
\text { persons }\end{array}$ & Faculty & $\begin{array}{c}\text { Chair- } \\
\text { persons }\end{array}$ & Faculty \\
\hline Increase & 50 & 62 & 71 & 75 \\
No Change & 47 & .33 & 28 & 24 \\
Decrease & 3 & 4 & 1 & 1 \\
\hline
\end{tabular}

Table 6

Constraints on Computer Use as Perceived by Psychology Chairpersons and Faculty

\begin{tabular}{lcc} 
& \multicolumn{2}{c}{ Percentage } \\
\cline { 2 - 3 } Constraint & Chairpersons & Faculty \\
\hline Lack of Faculty Training & 60 & $*$ \\
Lack of Student Training & $*$ & 28 \\
Lack of Equipment & 42 & 42 \\
Lack of Time & 37 & 52 \\
Lack of Interest & 32 & $*$ \\
Lack of Funds & 30 & 29 \\
Lack of Software & $*$ & 41 \\
Lack of Academic Rewards & $*$ & 36 \\
Lack of Support Help & $*$ & 33 \\
Lack of Need & 9 & $*$ \\
\hline
\end{tabular}

*Item not included in respective questionnaire.

Table 7

Faculty Rating of Factors Affecting Past and Future Changes in Instructional Computing

\begin{tabular}{lrllc}
\hline \multicolumn{2}{c}{ Past Changes } & & \multicolumn{2}{c}{ Future Changes } \\
Factor & $\begin{array}{c}\text { Percent- } \\
\text { age }\end{array}$ & & Factor & $\begin{array}{c}\text { Percent- } \\
\text { age }\end{array}$ \\
\hline Software & 66 & Software & 69 \\
Hardware & 50 & Hardware & 52 \\
Courses & 36 & Student Demand & 32 \\
Student Demand & 20 & Growth in Field & 20 \\
Growth in Field & 17 & Use of CAI & 19 \\
Staff Support & 16 & Number of Students & 18 \\
Use of CAl & 10 & On-Line Testing & 13 \\
On-Line Testing & 5 & & \\
\hline
\end{tabular}

instruction (see Table 7). For both types of changes, the most important factor was software, followed by hardware. Student demand was rated as a factor affecting past changes by only $20 \%$ of the faculty, but $32 \%$ indicated that student demand would be a factor influencing future changes. The past changes entry "courses" indicates changes in the individual faculty members' teaching responsibilities either toward or away from courses in which the use of instructional computing is appropriate.

\section{CHARACTERISTICS OF ACTUAL USAGE}

Another source of information concerning faculty activities in instructional computing is the manner in which the computer is actually used in courses. Table 8 summarizes responses to a series of questions dealing with the manner in which faculty members utilize computing resources in instruction in psychology. By far, the most prevalent use of computers in instruction in psychology is for demonstrations. Sixty-four percent of the faculty surveyed who use computers use them in demonstrations-either laboratory-type demonstrations or demonstrations especially designed for use in courses. Although there is only a slight prevalence $(53 \%)$ of interactive over batch computing as the primary mode of student-computer communication, the increase over the previous 2 years is dramatic. Large mainframes are used for $75 \%$ of the instructional computing reported, and microcomputers account for only $12 \%$. Of course, this survey was conducted just as microcomputers began to become plentiful and widely distributed; a survey today would probably show a large increase in the reported use. BASIC and FORTRAN are the most widely used programming languages, although "other" languages, from special-purpose control languages to $\mathrm{CAI}$ support languages, are widely used in a large number of variations that are often system dependent.

When queried about the sort of use students make of computers in their courses, faculty members reported that $75 \%$ of the use is for data analysis. Problem solving

Table 8

Characteristics of Faculty Computer Use

\begin{tabular}{lc}
\hline \multicolumn{1}{c}{ Pedagogy } & Percentage \\
\hline & \\
Demonstrations & 64 \\
Instructional Management & 33 \\
Test Scoring & 27 \\
Test Generation & 19 \\
Other & $<10$ \\
\multicolumn{1}{c}{ Mode of Student/Computer Dialogue } \\
Batch & 47 \\
Interactive & 53 \\
& \\
Large Mainframe & 75 \\
Minicomputer & 31 \\
Microcomputer & 12 \\
Programmable Calculator & 5 \\
& \\
BASIC & \\
FORTRAN & 47 \\
APL & 42 \\
PL/1 & 4 \\
COBOL & 4 \\
PASCAL & 3 \\
Others & 1 \\
&
\end{tabular}


and simulation/modeling account for $39 \%$ and $29 \%$, respectively, of student use in courses. These data are summarized in Table 9. The large percentage reported for data analysis is no doubt a function of the major importance that empirical data have in contemporary psychology. Data accumulation, the recording of data from experiments, is reported as a computer function for $27 \%$ of the students. This suggests that a surprisingly large number of students have access to laboratory computers. Perhaps more important than the type of computing done by students are the types of courses in which computers are used for instruction. Statistics and experimental methods courses account for a total of $42 \%$ of the courses reported that use computers. Table 10 summarizes the distribution of courses in which computers are used. It is rather surprising to see that at the time of the survey, there was no predominant substantive course that made use of instructional computing. The "other" category included special courses and independent study and research.

While the faculty members surveyed report relatively little use of instructional computing outside statistics courses, they see a clear need in a variety of substantive courses. Table 11 summarizes the subject matter that faculty members rated as suitable for development of instructional computing. Again, statistics was the predominant course mentioned ( $88 \%$ ). The substantive content judged most suitable for development of instructional computing was cognitive psychology, which is to be expected, since so much of the theoretical and empirical developments in the last decade have depended upon the use of computers in a crucial way. Other content areas judged suitable for development were sensory, physiological, social, and animal psychology. Clinical psychology was rated lowest, with only $11 \%$ of the faculty respondents indicating that the area was suitable for development of instructional materials.

Table 11 also summarizes the types of instructional computing materials that faculty members feel should be developed. Simulations and data analysis were the most frequently named types of materials. While it is clear that simulations should be developed on the basis of the

Table 9

Type of Computer Use by Students

\begin{tabular}{lc}
\hline & Percentage \\
\hline Data Analysis & 74 \\
Problem Solving & 39 \\
Simulation or Modeling & 29 \\
Data Accumulation & 27 \\
Learning Data Processing & 19 \\
Learning Programming & 19 \\
On-Line Testing & 9 \\
Drill and Practice & 9 \\
Tutorial Dialogues & 9 \\
Information Retrieval & 9 \\
Learning Electronics & 4 \\
Word Processing & 3 \\
\hline
\end{tabular}

Table 10

Types of Courses Using Computers $(N=545)$

\begin{tabular}{lc} 
& Percentage \\
Statistics & 24 \\
Experimental Methods & 12 \\
Experimental Design & 4 \\
Multivariate Analysis & 2 \\
Introductory Psychology & 8 \\
Research & 8 \\
Computer Applications & 8 \\
Social & 3 \\
Cognitive & 2 \\
Physiological & 2 \\
Sensory & 1 \\
Clinical & 0 \\
Other & 24 \\
\hline
\end{tabular}

Table 11

Faculty Perceptions of Instructional Computing Needs

\begin{tabular}{lc} 
& Percentage \\
\hline Topics Most Suitable for Instructional Computing \\
Statistics & 88 \\
Laboratory Methods & 71 \\
Cognitive Psychology & 43 \\
Sensory Psychology & 25 \\
Physiological Psychology & 23 \\
Social Psychology & 20 \\
Animal Psychology & 20 \\
Clinical Psychology & 11 \\
Other & 17 \\
Types of Materials That Should Be Developed \\
Simulations & 61 \\
Data Analysis & 60 \\
Tutorial Dialogues & 43 \\
Problem Solving & 30 \\
On-Line Testing & 28 \\
Programming Exercises & 26 \\
Games & 12 \\
Other & 8 \\
\hline
\end{tabular}

relatively low indicated use in substantive areas, it is surprising to see data analysis rated high as something that should be developed. This is due to a perceived lack of good instructional materials in statistics and data analysis, in spite of the large number of statistical packages like SPSS and BMD available.

\section{SUMMARY}

Surveys are always perplexing. The purpose of the CONDUIT state-of-the-art surveys is to summarize the state of instructional computing in several disciplines at a particular time. The information not only is useful in a descriptive sense but also can serve practical purposes in suggesting where development is rapid, where special needs exist, and where special resources in instructional computing may exist. Computing, especially instructional computing, is a rapidly changing area. Academic budgets and resources are constantly 
changing, as are the costs associated with computing. Inexpensive microcomputers are having a major effect on undergraduate education. A survey done today would undoubtedly show significant changes in patterns of instructional computing and clearly document the revolution that is changing the character of not only psychology, but education in general.

\section{REFERENCES}

Castellan, N. J., Jr., Bailey, D. E., Lehman, R. S., McClelland, G., \& Stark, B. J. Computers in teaching psychology: A state of the art report. In J. Johnson (Ed.), Computers in undergraduate teaching. Iowa City: CONDUIT, 1977. Cline, H. F. Social science computing, 1967-1972. Joint Computer Conference 40, Spring 1972, pp. 665-673. 